\title{
A Mixed Method Study for Investigating Critical Success Factors (CSFs) of E-Learning in Saudi Arabian Universities
}

\author{
Quadri Noorulhasan Naveed \\ Department of Information System, \\ KICT, International Islamic \\ University Malaysia,
Kuala Lumpur, Malaysia \\ University Malaysia,
Kuala Lumpur, Malaysia
}

Mohamed Rafik N. Qureshi

College of Engineering, King Khalid University, Kingdom

of Saudi Arabia

\author{
AbdulHafeez Muhammad \\ College of Computer Science, King \\ Khalid University, Kingdom of \\ Saudi Arabia
}

\author{
Sumaya Sanober \\ College of Arts and Science, \\ Prince Sattam Bin AbdulAziz \\ University, \\ Kingdom of Saudi Arabia
}

\author{
Asadullah Shah \\ Department of Information System, KICT, \\ International Islamic University Malaysia. \\ Kuala Lumpur, Malaysia
}

\begin{abstract}
Electronic Learning (E-Learning) in the education system has become the obvious choice of the community over the globe because of its numerous advantages. The main aim of the present study is to identify Critical Success Factors (CSFs) and validate them for successful implementation of the E-Leaning at Saudi Arabian Universities. This study developed a multidimensional instrument for measuring the E-Learning CSFs in the higher educational institutions of Saudi Arabia. The study reviewed various CSFs from literature and identified most important E-Learning CSFs which are described and grouped in five dimensions such as Student, Instructor, Design and Contents, System and Technological, and Institutional Management Services. The 36 CSFs falling under these relevant dimensions were then validated their importance quantitatively through university Students, Instructors, and E-Learning staffs of some well-known universities in Saudi Arabia. A survey instrument was developed and tested on a sample of 257 respondents of Saudi Arabia Universities. It was found that System and Technological dimension is the most significant as perceived by respondents. Results of the study discovered that all obtained factors are highly reliable and thus would be useful to develop and implement E-Learning systems.
\end{abstract}

Keywords-Critical Success Factors (CSFs); Content Reliability and Collected Mean; E-Learning, Kingdom of Saudi Arabia. Quantitative Analysis

\section{INTRODUCTION}

E-Learning has become a novel means of learning trend in current years. It can provide amusing resources than the traditional classroom to enhance ease of learning-learning. ELearning also overcomes the restrictions of time and space of traditional physical teaching. It allows users to study independently, with freedom with lesser or negligible interference [1]. However, if the E-Learning system is not followed correctly, it may not deliver the required quality education. Critical Success Factors (CSFs) play a vital role in enhancing the quality of the E-Learning organization. CSF came into a scenario in the literature when the comparison was made between some establishments, and the study was conducted to explore the components for success. The organization needs to hold CSFs well to have a successful implementation and also to measure CSFs as variables which are essential for the phase implementation [2]. CSFs are the variables that are required to measure in the phase of planning to ensure the process of execution. Hence, it is essential to verify, control, and measure to dictate the success of an entire system which results into achieving the quality standards of ELearning. The rapid growth of science leads to the new advancement of carrying learning content and enabling learnerinstructor communication. It is achieved globally using computer network acknowledged as E-Learning, educational revolution caused with the impact upon education all around the world [3]. It is very importance to study the critical success factors of E-Learning system, as well as to find the barriers of the E-Learning education system, and what enables the ELearning education system. The measure of successful implementation of E-Learning should incorporate different concepts and constructs to evaluate this success [1]. Any instrument that measures and identifies E-Learning CSFs from user or stakeholders' perception holds a significant importance for practitioners and researchers in the field. Educational institutions are also motivated to develop state-of-the-art ELearning systems that fulfil the expectations of Students and Instructors.

The main objectives of the present study are to investigate important factors for the successful implementation of $E$ Learning especially for Saudi Arabian Universities where researchers are involved practically in this filed. Kingdom of Saudi Arabia (KSA) is also embarking on E-Learning like other countries of the world because of the need of time and demand. It is the right time to investigate the critical success for Saudi E-Learning industry for its successful implantation.

The paper organization is as: Section 2 discusses related literature. Section 3 presents a description of the research 
methods and procedures used in generating the indicators of each E-Learning CSFs. In Section 4, the finding and results are discussed. Discussion and conclusions with future work are discussed in the last section of the paper.

\section{LITERATURE REVIEW}

\section{A. E-Learning}

E-Learning is becoming very important and gradually popular approach in higher educational institutions over the teaching and learning world because of its ability of resource sharing, cost effectiveness, flexibility, and easy availability of the World Wide Web (WWW). Ease of using the E-Learning technology tools through web resources, means of choice for distance education and professional training has made the ELearning technology extremely popular. In addition, to provide comfortable resources as compared to the traditional physical classroom teaching-learning, E-Learning also breaks the boundaries of time and space that limits the of traditional teaching-learning. E-Learning also allows independent learning that is free from direct observation of traditional teaching [1]. [4], view E-learning as "In a knowledge and information society, E-Learning is built on the extensive use of advanced information and communication technologies to deliver instructions". [5] refer E-Learning as, "the use of various technological tools that are web based, web distributed, or web capable for the purposes of education". [6] defined E-Learning as, "the use of Information and Communication Technology to enhance and support learning in tertiary education". [7] refers, "E-Learning as the wide set of applications and processes, which uses available electronic media and tools to deliver vocational education and training". Open and Distance Learning Quality Council of UK states "E-Learning to be an effective learning process created by combining digitally delivered content with learning support and services". [8] considered E-Learning as, "an electronically mediated interaction". Other terminologies, such as: online education, online learning, E-Education, M-Learning, and open and distance learning are used for the term E-Learning in different research studies. [9] highlighted that; E-Learning in the education system has become the obvious choice of masses over the globe because of its numerous advantages. However, E-Learning system may not deliver the required quality education if not followed and utilized correctly. The Kingdom of Saudi Arabia (KSA) is the largest Arab country by land in Western Asia which occupies a major part of the Arabian Peninsula, with the Persian Gulf to the east, the Gulf of Aqaba and the Red Sea in the west. In 1975, the Saudi Arabian government formed Ministry of Higher Education to supervise country's Higher Educational System. The Ministry set longterm objectives and plans with huge resources to provide skilled manpower to look after the nation's increasing economy, both in government, and private sectors. The Saudi Ministry of Higher Education also accepted the high possibilities and need of E-Learning in public universities, where there is a scarcity of female staff members in the gender based institutions. A large number of students also interested and desire for studying part time to get better employment [10] [11].

\section{B. E-Learning Critical Success Factors (CSFs)}

In the late 1970s, CSF appears in literature because of the problem about the indication of some establishments which seemed to be more fortunate and successful comparing with others. The research was conducted to study about the success components of some successful business (Ingram et al., 2000). CSF is considered as an important factor for fulfilling organizational mission and vision. It also can be said that due to lack of these factors, the organizational mission can be failed [12]. A number of CSF definitions were acquainted with several kinds of literature. [13] explained the CSF concept as, "... the limited number of areas in which results, if they are satisfactory, will ensure successful competitive performance for the organization. They are the few key areas where 'things must go right' for the business to flourish". In the year 1988, Freund presented CSFs as, "those things that must be done if a company is to be successful". CSFs must be limited in numbers, and should be measurable and controllable. [14] proposed that CSFs should be treated as a model or framework for strategic planning in directing stakeholders to determine the elements which should be treated right in succeeding the targeted goals and objectives. [2], studied about CFS and considered the term as the variables which are essential for the success in the stage of implementation. So, in order to achieve a fruitful implementation, an organization has to handle CSFs very well. The previous definition proves that, CSFs are the features and variables which must be treated carefully throughout the planning phase to confirm the robust execution of a project. Consequently, CSFs should be verifiable, measurable, and controllable to ensure the success of the whole system. In short, to achieve the success of an organization, CSFs must be taken care of in a critical manner. Many researchers have tried to know the reasons for E-Learning success or failure. Therefore, many factors exist to determine the success of E-Learning. As [14] pointed out, many projects on E-Learning failed because of unawareness of their main objectives and goals, resulting many to question on the capabilities, quality and electronic form of education. According to [2], the complete recognition of the factors which are important and influence effectiveness of E-Learning systems will help and facilitate institutions towards added funding. It also reduces the waste of funding and efforts on non-productive factors. Finally, the research that leads to uncovering the E-Learning CSFs will be critical to understanding the crux of E-Learning effectiveness and success.

\section{METHODS AND PROCEDURE}

To achieve the objective of the study, i.e. investigation of CSF for the successful and effective E-Learning implementation at Saudi Arabian universities, a mixed method was used. At the beginning of the study, recent literature was reviewed in detail and analysed to determine and conclude the items relevant to Critical Success Factors (CSFs) with different dimension through content analysis qualitative techniques. A total of 64 papers, published during 2005-2016, were selected from IEEE, Emerald Publishers, ScienceDirect, Taylor and Francis, Springer, and Google scholar databases. The methodology adopted for the present research were analysed 
and synthesized using one of the popular qualitative techniques with content analysis.

Later, to validate the extracted factors, a survey approach was used involving 247 staff members of different universities in Saudi Arabia. SPSS (Statistical Package for the Social Sciences) v22 Windows software program is used to analyse the responses of the survey. In the beginning, the initial design draft of the survey instrument was reviewed by four experience staff members with more than 5 years of experiences in teaching and managing E-Learning courses to establish the content validity of the instrument. The survey comprises of two main parts. First part contains demographic questions on the association of E-Learning, Gender, College of Teaching or Studying, E-Learning experience (number of years as an ELearning user), Designation, University name, Purpose and Frequency of using E-Learning teaching, and University. The second part is divided into five dimensions, namely: Student, Instructor, Design and Contents, System and Technological dimension, and Institutional Management Service with 36 factors of CSFs. The survey consists of five-point scale items (1 for Not Important, 2 for Slightly Important, 3 for Moderately Important, 4 for Important, and 5 for Very Important)

\section{A. Content Validity Analysis}

Initially the survey instrument was sent and reviewed by four experienced instructors to check on the following issues:

1) The importance of the Dimensions and Factors to the ELearning success

2) The degree of the clarity, content, and difficulty of the items

The experienced instructors have agreed that the items are applicable based on the current research objectives and the items are representative to check the importance of the factors for successful E-Learning and its effectiveness.

Table 1 shows the experienced instructors' rating opinion on the content validity of each dimension. Only items from the survey which are rated by the experts as "Agree" and "Strongly Agree" are selected in calculating the Content Validity Index (CVI). As all four experts rated "Agree" or "Strongly Agree" on all the items in the survey, the overall content validity index is 1.00 .

\section{B. Reliability Analysis}

Reliability is normally defined by measuring the internal uniformity of components with the uses of Cronbach's alpha $(\alpha)$, which is commonly used to measure the inner consistency. It presents integrity strength of a set of items in a group or dimension. The factor is carefully weighed as a degree of scale reliability. A high value of Cronbach's alpha $(\alpha)$ does not indicate the degree as uni-dimensional. To evaluate inner consistency, the value of alpha will provide evidence of the scale as uni-dimensional and additional examinations or research may be conducted on the point. Another method, known as exploratory factor analysis, is used to check the dimensionality. Basically, the Cronbach's alpha $(\alpha)$ is not representing a statistical value. The alpha is nothing but a coefficient of consistency or reliability. The alpha $(\alpha)$ which is presented in Eq. (1), is a function of test item number $(\mathrm{N})$ and an average of inter-correlation.
TABLE I. EXPERIENCED INSTRUCTORS' RATING ON THE CONTENT VALIDITY OF EACH DIMENSION

\begin{tabular}{|c|c|c|c|c|c|}
\hline Items & 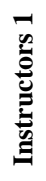 & 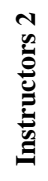 & 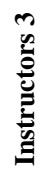 & 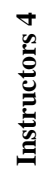 & 己 \\
\hline Student's Dimension & $\sqrt{ }$ & $\sqrt{ }$ & $\sqrt{ }$ & $\sqrt{ }$ & 1.00 \\
\hline Instructor's Dimension & $\sqrt{ }$ & $\sqrt{ }$ & $\sqrt{ }$ & $\sqrt{ }$ & 1.00 \\
\hline Design \& Contents' Dimension & $\sqrt{ }$ & $\sqrt{ }$ & $\sqrt{ }$ & $\sqrt{ }$ & 1.00 \\
\hline $\begin{array}{c}\text { System and Technological } \\
\text { Dimension }\end{array}$ & $\sqrt{ }$ & $\sqrt{ }$ & $\sqrt{ }$ & $\sqrt{ }$ & 1.00 \\
\hline $\begin{array}{c}\text { Institutional Management } \\
\text { Dimension }\end{array}$ & $\sqrt{ }$ & $\sqrt{ }$ & $\sqrt{ }$ & $\sqrt{ }$ & 1.00 \\
\hline & $N$ & & & & (1) \\
\hline
\end{tabular}

Here, $\mathrm{N}$ is presenting the item number, $\bar{v}$ is presenting the average variance, and $\overline{\mathrm{c}}$ is indicating the average inter-item covariance of the test items.

It is clearly seen from Eq. (1) that, if the number of items $(\mathrm{N})$ is increased by some value, Cronbach's alpha $(\alpha)$ will increase. On the other hand, with the decreasing value of average inter-item correlation, Cronbach's alpha $(\alpha)$ will be decreased. Moreover, with the increment of the average value of inner-item correlation, the alpha value will be in increasing as well.

High reliability exists in the instrument with the value of 0.982 based on 36 items, which is transcending the level of minimum value (0.80). Table 2 shows the Cronbach's Alpha reliability coefficient for each of the five Dimensions: Student $=0.891$, Instructor $=0.941$, Design and Contents $=0.946$, System and Technological $=0.928$, and Institutional Management Service $=0.921$.

TABLE II. RELIABILITY ANALYSIS CRITICAL SUCCESS FACTOR

\begin{tabular}{lll}
\hline Dimensions & $\begin{array}{l}\text { No of } \\
\text { Items }\end{array}$ & $\begin{array}{l}\text { Cronbach's } \\
\text { Alpha }\end{array}$ \\
\hline Students' Dimension & 7 & 0.891 \\
\hline Instructors' Dimension & 7 & 0.941 \\
\hline Design \& Contents Dimension & 8 & 0.946 \\
\hline System and Technology Dimension & 8 & 0.928 \\
\hline Institutional Management Service & 6 & 0.921 \\
\hline Total & 36 & 0.982 \\
\hline & (Source: Calculation from Primary data using SPSS 22.0)
\end{tabular}




\section{REULTS AND DISCUSSIONS}

After reviewing the detailed literature, the study identified 36 most important E-Learning CSFs which were grouped in five dimensions having the same theme such as: 1) Student, 2) Instructor, 3) Design and Contents, 4) System and Technological Factor, and 5) Institutional Management Service. Each dimension included several factors that can be explained as follows:

\section{A. Students'Dimension}

"An E-Learning system is the student centred approach in which students are the main stakeholders and perceived beneficiaries from the system" [15]. Students recognise benefits using E-Learning systems. Without proper usages of the E-Learning, this system has no value. Students have become more active and advance while the demand for education awareness is increasing. For example, there are lots of new demand coming for formal education from nontraditional female students with grown children, full-time students who work part-time during their off time, and enthusiastic part-time students who work full time. For satisfying and getting benefits from E-Learning, student's factor is considered as important. Various individualities of student have great prospective to influence E-Learning system. Table 3 shows the important factors that are falling under the student's dimension from different resources.

TABLE III. CRITICAL SUCCESS FACTOR (CSFs): StUdENT's DimENSION

\begin{tabular}{ll}
\hline \multicolumn{1}{c}{ Factors } & \multicolumn{1}{c}{ Resources / References } \\
\hline $\begin{array}{l}\text { Students' Attitude and towards } \\
\text { E-Learning }\end{array}$ & {$[16],[17],[18],[19],[20],[21],[22]$,} \\
& {$[23],[2]$} \\
\hline Students' Motivation & {$[19],[24],[25],[26],[27],[28]$} \\
\hline $\begin{array}{l}\text { Computer Competency (ICT } \\
\text { skills) }\end{array}$ & {$[16],[18],[17],[18],[19],[24],[25]$,} \\
& {$[26],[22],[29],[2],[30],[3]$} \\
\hline Computer Anxiety & {$[18],[20],[21]$} \\
\hline Interaction with other Students & {$[16],[20],[31],[29],[29],[32],[2],[30]$} \\
& {$[20],[25],[26],[33]$} \\
\hline Commitment & {$[34],[35],[36],[20],[21],[37],[28]$,} \\
& {$[3]$} \\
\hline $\begin{array}{l}\text { Learners General and Internet } \\
\text { Self-efficacy }\end{array}$
\end{tabular}

Quantitative analysis has been conducted on the data collected through questionnaire survey for Students' Dimension and is tabulated in Table 4. From the results obtained, it may be concluded that, the majority of the respondents who confirms the importance of factors responsible for successful implementation of E-Learning has the mean range value (3.04 to 3.61). The further conclusion can also be drawn from the Table 4 that, the highest mean value (3.61) is found for "Students' Motivation" which holds the place of a most significant factor for the successful implementation of E-Learning. Contrarily, "Interaction with other students" has the least mean value (3.04), thus become less significant for the successful implementation of ELearning. The average mean value (3.32) is obtained for all factors in Student's Dimension.
TABLE IV. CRITICAL SUCCESS FACTOR (CSFs): StUdENT'S DiMENSION

\begin{tabular}{lccc}
\hline \multicolumn{1}{c}{ Factors } & Mean & N & $\begin{array}{c}\text { Std. } \\
\text { Deviation }\end{array}$ \\
\hline Attitude towards E-Learning & 3.35 & 257 & 1.353 \\
\hline Students' Motivation & 3.61 & 257 & 1.316 \\
\hline Computer Competency (ICT Skills) & 3.29 & 257 & 1.043 \\
\hline Computer Anxiety & 3.07 & 257 & 1.104 \\
\hline Interaction with other Students & 3.04 & 257 & 1.241 \\
\hline Commitment towards Online Studies & 3.53 & 257 & 1.173 \\
\hline General Internet Self-Efficacy & 3.32 & 257 & 1.118 \\
\hline & & & \\
\hline
\end{tabular}

\section{B. Instructors' Dimension}

It is also an important dimension to assist towards student satisfaction of E-Learning. The effective and successful implementation of learning management systems is really based on the Instructors' attitude towards E-Learning execution. Mostly, student satisfactions and taking of online EEducation are influenced by teacher's teaching style, his approach towards conducting lectures in a friendly manner, and providing quality and useful content. Characteristics of the Instructors are important determinants that affect and influence the productivity and usefulness of learning management systems. Table 5 shows the factors with resources of this dimension.

TABLE V. CRITICAL SUCCESS FACtOR (CSFs): INSTRUCTORS' DIMENSION

\begin{tabular}{ll}
\hline Factors & Resources / References \\
\hline $\begin{array}{l}\text { Instructors' Attitude } \\
\text { towards E-Learning }\end{array}$ & $\begin{array}{l}{[16],[38],[18],[19],[36],[25],[21],[25],} \\
{[26],[23]}\end{array}$ \\
\hline Instructors' ICT Skills & $\begin{array}{l}{[16],[38],[17],[19],[24],[20],[31],[25],} \\
{[26],[22],[2],}\end{array}$ \\
\hline Cultural Awareness & {$[39],[17],[40],[41]$} \\
\hline $\begin{array}{l}\text { Easy Language } \\
\text { Communication }\end{array}$ & {$[20],[27],[23]$} \\
\hline $\begin{array}{l}\text { Interaction with } \\
\text { Students }\end{array}$ & {$[17],[20],[43],[25],[44],[26],[45],[22]$,} \\
\hline Appropriate Timely & {$[18],[20],[25],[21],[45]$} \\
Feedback & {$[22]$} \\
\hline Self-Efficacy & {$[38],[34],[20],[22]$} \\
\hline
\end{tabular}


Quantitative analysis has been conducted on the data collected through questionnaire survey for Instructors' Dimension and is tabulated in Table 6. From the results obtained, it may be concluded that, the majority of the respondents who confirms the importance of factors responsible for successful implementation of E-Learning has the mean range value (3.29 to 3.70). The further conclusion can also be drawn from the Table 6 that, the highest mean value (3.70) is found for "Appropriate Timely Feedback" which holds the place of a most significant factor for the successful implementation of E-Learning. Contrarily, "Cultural Awareness" has the least mean value (3.29), thus become less significant for the successful implementation of E-Learning. The average mean value (3.55) is obtained for all factors in Student's Dimension.

TABLE VI. CRITICAL SUCCESS FACTORS (CSFS): INSTRUCTORS' DIMENSION

\begin{tabular}{lccc}
\hline \multicolumn{1}{c}{ Factors } & Mean & N & $\begin{array}{c}\text { Std. } \\
\text { Deviation }\end{array}$ \\
\hline Instructors' Attitude towards E-Learning & 3.64 & 257 & 1.342 \\
\hline Instructors' ICT skills & 3.60 & 257 & 1.205 \\
\hline Cultural Awareness & 3.29 & 257 & 1.105 \\
\hline Easy Language Communication & 3.61 & 257 & 1.126 \\
\hline Interaction with Students & 3.58 & 257 & 1.144 \\
\hline Appropriate Timely Feedback & 3.70 & 257 & 1.224 \\
\hline Self-Efficacy & 3.45 & 257 & 1.114 \\
\hline Average & 3.55 & -- & -- \\
\hline & (Source: Calculation from Primary data using SPSS 22.0)
\end{tabular}

\section{Design and Content's Dimension}

Design and Content are the third dimensions which also considered as important and have a huge effect on the ELearning success. Well designed and understandable courses and contents, learning materials and activity, and curriculum, facilitate meaningful educational experiences. User friendly interface and clear contents of online E-Learning course will affect student's pleasure and satisfaction. Table 7 shows the factors with resources of this dimension.

TABLE VII. CRITICAL SUCCESS FACTOR (CSFS): DESIGN AND CONTENT'S DIMENSION

\begin{tabular}{ll}
\hline \multicolumn{1}{c}{ Factors } & \multicolumn{1}{c}{ Resources / References } \\
\hline Interactive Learning Activity & {$[46],[16],[34],[20],[22],[32],[47]$,} \\
\hline Appropriate Course Design & {$[16],[20],[23],[48]$} \\
\hline Use of Multimedia Instruction & {$[38],[34],[45]$,} \\
\hline
\end{tabular}

User-Friendly Organized

[46], [18], [20], [25], [49], [50], [47]

Course Flexibility

[22], [50], [51]

Understandable Content

[20], , [25],[26], [22], [50], [50]

Sufficient Updated Content

[25], [26], [40], [47]

Perceived Ease of Use

[18], [49], [21], [32], [47]
Quantitative analysis has been conducted on the data collected through questionnaire survey for Design and Contents' Dimension and is tabulated in Table 8. From the results obtained, it may be concluded that, the majority of the respondents who confirms the importance of factors responsible for successful implementation of E-Learning has the mean range value ( 3.32 to 3.71 ). The further conclusion can also be drawn from the Table 8 that, the highest mean value (3.71) is found for "User -Friendly Organized" which holds the place of a most significant factor for the successful implementation of E-Learning. Contrarily, "Course Flexibility" has the least mean value (3.32), thus become less significant for the successful implementation of E-Learning. The average mean value (3.55) is obtained for all factors in Student's Dimension.

TABLE VIII. CRITICAL SUCCESS FACTOR (CSFs): DESIGN AND CONTENTS' DIMENSION

\begin{tabular}{lccc}
\hline \multicolumn{1}{c}{ Factors } & Mean & N & $\begin{array}{c}\text { Std. } \\
\text { Deviation }\end{array}$ \\
\hline Interactive Learning Activity & 3.55 & 257 & 1.369 \\
\hline Appropriate Course Design & 3.68 & 257 & 1.317 \\
\hline Use of Multimedia Instruction & 3.52 & 257 & 1.094 \\
\hline User -Friendly Organized & 3.71 & 257 & 1.184 \\
\hline Course Flexibility & 3.32 & 257 & 1.121 \\
\hline Understandable Content & 3.65 & 257 & 1.157 \\
\hline Sufficiently Updated Content & 3.42 & 257 & 1.200 \\
\hline Perceived Ease of Use & 3.53 & 257 & 1.163 \\
\hline Average & 3.55 & -- & -- \\
\hline
\end{tabular}

\section{System and Technological Dimension}

System and Technology play a significant role in providing learning outcomes, as the students cooperate more in the ELearning environs through Internet Technology [52]. In an ELearning environment, students also use other tools, such as: video or audio conferencing and text messaging or chat, more than the traditional conversation or face-to-face instruction. To acquire successful implementation of E-Learning system and obtain students' satisfaction with the system, there should be a great quality in technological attributes. Table 9 shows the factors with resources of this dimension.

TABLE IX. CRITICAL SUCCESS FACTOR (CSFS): SYSTEM AND TECHNOLOGICAL DIMENSION

\begin{tabular}{ll}
\hline \multicolumn{1}{c}{ Factors } & \multicolumn{1}{c}{ Resources / References } \\
\hline Appropriate System & {$[46],[44],[45],[23]$} \\
\hline Ease of Access & {$[16],[48],[48]$} \\
\hline Technical Support for & {$[22],[21],[27],[45],[2],[51],[53],[47]$,} \\
Users & {$[16],[17],[18],[19],[21],[45],[29],[33]$} \\
\hline \multirow{2}{*}{ Good Internet Speed } & {$[22],[48],[3]$} \\
\hline Efficient Technology & {$[16],[18],[31],[43][29],[48],[54],[26],[23]$,} \\
Infrastructure & {$[51],[48],[30],[42],[41],[55],,[3]$} \\
\hline Ease of Use & {$[20],[25],[29],[22],[47],[50],[47],[56]$} \\
\hline Reliability & {$[20],[25],[22],[56],[26],[45],[29],[23],[33]$,} \\
\hline Network Security & {$[51],[50],[47]$} \\
\hline
\end{tabular}


Quantitative analysis has been conducted on the data collected through questionnaire survey for System and Technological Dimension and is tabulated in Table 10. From the results obtained, it may be concluded that, the majority of the respondents who confirms the importance of factors responsible for successful implementation of E-Learning has the mean range value (3.31 to 3.93). The further conclusion can also be drawn from the Table 10 that, the highest mean value (3.93) is found for "Good Internet Speed" which holds the place of a most significant factor for the successful implementation of E-Learning. Contrarily, "Network Security" has the least mean value (3.31), thus become less significant for the successful implementation of E-Learning. The average mean value (3.63) is obtained for all factors in Student's Dimension.

TABLE X. CRITICAL SUCCESS FACTOR (CSFs): SYSTEM AND TECHNOLOGICAL DIMENSION

\begin{tabular}{lccc}
\hline \multicolumn{1}{c}{ Factors } & Mean & N & $\begin{array}{c}\text { Std. } \\
\text { Deviation }\end{array}$ \\
\hline Appropriate System & 3.57 & 257 & 1.324 \\
\hline Ease of Access & 3.61 & 257 & 1.298 \\
\hline Technical Support for Users & 3.78 & 257 & 1.125 \\
\hline Good Internet Speed & 3.93 & 257 & 1.188 \\
\hline Efficient Technology Infrastructure & 3.70 & 257 & 1.124 \\
\hline Ease of Use & 3.59 & 257 & 1.136 \\
\hline Reliability & 3.54 & 257 & 1.139 \\
\hline Network Security & 3.31 & 257 & 1.309 \\
\hline Average & 3.63 \\
\hline \multicolumn{4}{c}{} \\
\hline
\end{tabular}

\section{E. Institutional Management Service Dimension}

Institutional Management Service dimension addresses organizational support for successful E-Learning. Following are the important factors related to Institutional Management Service. Table 11 shows the factors with resources of this dimension.

TABLE XI. CRITICAL SUCCESS FACTOR (CSFS): DESIGN AND CONTENT'S DIMENSION

\begin{tabular}{ll}
\hline \multicolumn{1}{c}{ Factors } & \multicolumn{1}{c}{ Resources / References } \\
\hline Infrastructure Readiness & {$[39],[35],[43],[25],[45],[23],[2]$,} \\
\hline Financial Readiness & {$[20],[43],[25],[26],[51],[40]$,} \\
\hline Training for User & {$[39],[23],[2],[51],[53],[40]$} \\
\hline Support for Faculty & {$[19],[24],[2]$} \\
\hline Ethical \& Legal Issues & {$[20]$} \\
\hline Proper feedback & {$[35],[25],[26],[23]$} \\
\hline
\end{tabular}

Quantitative analysis has been conducted on the data collected through questionnaire survey for Institutional Management Dimension and is tabulated in Table 12. From the results obtained, it may be concluded that, the majority of the respondents who confirms the importance of factors responsible for successful implementation of E-Learning has the mean range value (3.37 to 3.74). The further conclusion can also be drawn from the Table 12 that, the highest mean value (3.74) is found for "Training for User" which holds the place of a most significant factor for the successful implementation of E-Learning. Contrarily, "Ethical and Legal Issues" has the least mean value (3.37), thus become less significant for the successful implementation of E-Learning. The average mean value (3.58) is obtained for all factors in Student's Dimension.

TABLE XII. CRITICAL SUCCESS FACTOR (CSFS): INSTITUTIONAL MANAGEMENT DIMENSION

\begin{tabular}{lccc}
\hline \multicolumn{1}{c}{ Factors } & Mean & N & $\begin{array}{c}\text { Std. } \\
\text { Deviation }\end{array}$ \\
\hline Infrastructure Readiness & 3.51 & 257 & 1.355 \\
\hline Financial Readiness & 3.64 & 257 & 1.379 \\
\hline Training for User & 3.74 & 257 & 1.161 \\
\hline Support for faculty & 3.73 & 257 & 1.160 \\
\hline Ethical and Legal Issues & 3.37 & 257 & 1.132 \\
\hline Proper feedback & 3.46 & 257 & 1.186 \\
\hline Average & 3.58 & -- & -- \\
\hline
\end{tabular}

\section{CONCLUSION}

Authors have developed a multi-dimensional instrument for measuring the E-Learning CSFs in the higher educational institutions of Saudi Arabia. 36 CSFs which are the most significant in effective and successful E-Learning implementation in Saudi Higher Educational Institutes were derived from literature. Present research identifies E-Learning variables and their effect on the use of E-Learning and its successful implementation. The findings from the content validity analysis and reliability analysis of the instrument indicate the high validity and reliability of the system. Thus, researchers may suggest taking care of these factors during the implementation of E-Learning systems. Data collected from this study and previous researches reflect differences in Cronbach's alpha values. This may be because of the respondent's background, curricula, culture, facilities, or the items used in the instrument. This study considers all five dimensions of E-Learning, which are Student, Instructor, Design and Contents, System and Technological Dimension, and Institutional Management Service. It was found that System and Technological Dimension having mean 3.63 is the most significant while Students' Dimension having mean 3.32 is least significant as perceived by respondents. Moreover, Good Internet Speed Factor having mean 3.93 is most significant among all thirty-six factors while Interaction with other Students is least significant with mean value as 3.04. This study reviewed the most important CSFs for E-Learning acquired from the extensive literature survey and developed a survey instrument for the effectiveness of E-Learning system. It can be concluded that, Student, Instructor, Design and Contents, System and Technological dimensions, and Institutional Management Service are the most important success factor dimensions to influences the usages of ELearning systems. Thus institutions may be recommended that, they should provide more attention to the identified factors of 
E-Learning to ensure successful implementation of an ELearning system. The questionnaire used in this study focuses on the perceived effect of each factor dimension based on overall E-Learning effectiveness. It is further, recommended to make use of the present developed instrument in various contexts for the purpose of developing, implementing, and assessing E-Learning systems in a meaningful way. Another prospective could be the implementation of an E-Learning model, and investigating its learning effectiveness. Furthermore, the factors incorporating all the five dimensions can be prioritized to find more effective factors. Assessment of critical success factors contributes significantly to effective ELearning process. However, the influence of such CSF may vary from region to region depending on the social, economic, and geographical conditions of a country. In this research, assessment and prioritization have been established in the KSA.

\section{REFERENCES}

[1] T. H. Wang, "Developing Web-based assessment strategies for facilitating junior high school students to perform self-regulated learning in an e-Learning environment," Comput. Educ., vol. 57, no. 2, pp. 1801$1812,2011$.

[2] M. F. Frimpon, "A re-structuring of the critical success factors for elearning deployment," Am. Int. J. Contemp. Res., vol. 2, no. 3, pp. 115$127,2012$.

[3] F. Bahramnezhad, P. Asgari, S. Ghiyasvandian, M. Shiri, and F. Bahramnezhad, "The Learners' Satisfaction of E-learning: A Review Article," Am. J. Educ. Res., vol. 4, no. 4, pp. 347-352, 2016.

[4] N. J. Navimipour and B. Zareie, "A model for assessing the impact of elearning systems on employees satisfaction," Comput. Human Behav., vol. 53, pp. 475-485, 2015

[5] A. Muhammad, M. F. M. D. Ghalib, F. Ahmad, Q. N. Naveed, and A. Shah, "A Study to Investigate State of Ethical Development in ELearning,” J. Adv. Comput. Sci. Appl., vol. 7, no. 4, 2016.

[6] P. Boezerooij, E-learning strategies of higer education institutions: an exploraty study into the influence of environmental contingencies on strategic choices of higher education institutions with respect to integrating e-learning in their education delivery and suppor. University of Twente, CHEPS, 2006.

[7] Z. Abbas, M. Umer, M. Odeh, R. McClatchey, A. Ali, and A. Farooq, "A semantic grid-based e-learning framework (SELF)," in Cluster Computing and the Grid, 2005. CCGrid 2005. IEEE International Symposium on, 2005, vol. 1, pp. 11-18.

[8] C. Beard, J. P. Wilson, R. McCarter, and others, "Towards a Theory of E-learning: Experiential e-learning," J. Hosp. Leis. Sport Tour. Educ., vol. 6, no. 2, pp. 3-15, 2007.

[9] T. Unwin, "Survey of e-Learning in Africa," E-Learning Africa, pp. 1$10,2008$.

[10] H. S. Al-Khalifa, "E-Learning and ICT Integration in Colleges and Universities in Saudi Arabia.," eLearn Mag., vol. 2010, no. 3, p. 3, 2010.

[11] A. Muhammad, F. Ahamd, and A. Shah, "Resolving Ethical Dilemma in Technology Enhanced Education through smart mobile devices," Int. Arab J. e-Technology, vol. 4, no. 1, pp. 25-31, 2015.

[12] Y. P. Freund, "Critical success factors," Plan. Rev., vol. 16, no. 4, pp. 20-23, 1988.

[13] J. F. Rockart and W. P. Sloan, "INFORMATION SYSTEMS EXECUTIVE: A CRITICAL SUCCESS FACTORS PERSPECTIVE," 1982.

[14] M. R. Osman, R. M. Yusuff, S. H. Tang, and S. M. Jafari, "ERP systems implementation in Malaysia: the importance of critical success factors," Int. J. Eng. Technol., vol. 3, no. 1, pp. 125-131, 2006.

[15] O. XaymoungNhoun, W. Bhuasiri, J. J. Rho, H. Zo, and M.-G. Kim, "The critical success factors of e-learning in developing countries," Korea, vol. 305, p. 701, 2012.

[16] H. M. Selim, "Critical success factors for e-learning acceptance:
Confirmatory factor models," Comput. Educ., vol. 49, no. 2, pp. 396413, 2007.

[17] P. Gannon-Leary and E. Fontainha, "Communities of Practice and virtual learning communities: benefits, barriers and success factors," Barriers Success Factors. eLearning Pap., no. 5, 2007.

[18] P.-C. Sun, R. J. Tsai, G. Finger, Y.-Y. Chen, and D. Yeh, "What drives a successful e-Learning? An empirical investigation of the critical factors influencing learner satisfaction," Comput. Educ., vol. 50, no. 4, pp. $1183-1202,2008$.

[19] M. P. Menchaca and T. A. Bekele, "Learner and instructor identified success factors in distance education," Distance Educ., vol. 29, no. 3, pp. 231-252, 2008.

[20] S. Ozkan and R. Koseler, "Multi-dimensional students' evaluation of elearning systems in the higher education context: An empirical investigation," Comput. Educ., vol. 53, no. 4, pp. 1285-1296, 2009.

[21] M. W. Malik, "Factor Effecting Learner's Satisfaction Towards ELearning: A Conceptual Framework," OIDA Int. J. Sustain. Dev., vol. 2, no. 3, pp. 77-82, 2010.

[22] W. Bhuasiri, O. Xaymoungkhoun, H. Zo, J. J. Rho, and A. P. Ciganek, "Critical success factors for e-learning in developing countries: A comparative analysis between ICT experts and faculty," Comput. Educ., vol. 58, no. 2, pp. 843-855, 2012.

[23] T. FitzPatrick, "Key Success Factors of eLearning in Education: A Professional Development Model to Evaluate and Support eLearning.," Online Submiss., 2012.

[24] A. Andersson, "Seven major challenges for e-learning in developing countries: Case study eBIT, Sri Lanka," Int. J. Educ. Dev. using ICT, vol. 4 , no. 3, 2008 .

[25] M. Mosakhani and M. Jamporazmey, "Introduce critical success factors (CSFs) of elearning for evaluating e-learning implementation success," in Educational and Information Technology (ICEIT), 2010 International Conference on, 2010, vol. 1, pp. V1--224.

[26] M. R. Mehregan, M. Jamporazmey, M. Hosseinzadeh, and M. Mehrafrouz, "Proposing an approach for evaluating e-learning by integrating critical success factor and fuzzy AHP," in International Conference on Innovation, Management and Service, Singapore, 2011.

[27] C.-C. Lin, Z. Ma, and R. C.-P. Lin, "Re-examining the Critical Success Factors of e-learning from the EU perspective," Int. J. Manag. Educ., vol. 5, no. 1, pp. 44-62, 2011.

[28] A. C. Ordóñez, "Predicting International Critical Success Factors in elearning," Universitat Oberta de Catalunya, 2014.

[29] M. A. Musa and M. S. Othman, "Critical success factor in e-Learning: an examination of technology and student factors," Int. J. Adv. Eng. Technol., vol. 3, no. 2, p. 140, 2012.

[30] N. Laily, A. Kurniawati, and I. A. Puspita, "Critical success factor for elearning implementation in Institut Teknologi Telkom Bandung using Structural Equation Modeling," in Information and Communication Technology (ICoICT), 2013 International Conference of, 2013, pp. 427432.

[31] C. L. Goi and P. Y. Ng, "E-learning in Malaysia: Success factors in implementing e-learning program," Int. J. Teach. Learn. High. Educ., vol. 20, no. 2, pp. 237-246, 2009.

[32] W. Premchaiswadi, P. Porouhan, and N. Premchaiswadi, "An empirical study of the key success factors to adopt e-learning in Thailand," in Information Society (i-Society), 2012 International Conference on, 2012, pp. 333-338.

[33] G. Puri, "Critical success Factors in e-Learning--An empirical study," Int. J. Multidiscip. Res., vol. 2, no. 1, pp. 149-161, 2012.

[34] S.-S. Liaw, "Investigating students perceived satisfaction, behavioral intention, and effectiveness of e-learning: A case study of the Blackboard system," Comput. Educ., vol. 51, no. 2, pp. 864-873, 2008.

[35] E. Stacey and P. Gerbic, "Success factors for blended learning," Hello! Where are you Landsc. Educ. Technol. Proc. ascilite Melb. 2008, pp. 964-968, 2008.

[36] S. Yong-gui, L. Pu, H. Chunping, and C. Nai, "What Drives a Successful E-Learning? A Comparative Research between China Mainland and Taiwan," in Intelligent Information Technology Application Workshops, 2008. IITAW'08. International Symposium on, 
2008, pp. 961-966.

[37] W. Bhuasiri, O. Xaymoungkhoun, H. Zo, J. J. Rho, and A. P. Ciganek, "Critical success factors for e-learning in developing countries: A comparative analysis between ICT experts and faculty," Comput. $\{\&\}$ Educ., vol. 58, no. 2, pp. 843-855, 2012.

[38] S.-S. Liaw, H.-M. Huang, and G.-D. Chen, "Surveying instructor and learner attitudes toward e-learning," Comput. Educ., vol. 49, no. 4, pp. 1066-1080, 2007.

[39] B. H. Khan, E-learning quick checklist. IGI Global, 2005.

[40] S. A. OdunaiNe, O. O. Olugbara, and S. O. Ojo, "E-learning Implementation Critical Success Factors," innovation, vol. 3, p. 4, 2013.

[41] Y. F. A. Wibowo and K. A. Laksitowening, "Redefining e-learning readiness model," in Information and Communication Technology (ICoICT), 2015 3rd International Conference on, 2015, pp. 552-557.

[42] H. A. A. Alamin and E. E. A. Elgabar, "Success Factors for Adopting Elearning Application in Sudan," Int. J. Soft Comput. Eng., vol. 3, no. 6, 2014.

[43] B. Sridharan, H. Deng, and B. Corbitt, "Critical success factors in elearning ecosystems: a qualitative study,” J. Syst. Inf. Technol., vol. 12, no. 4, pp. 263-288, 2010.

[44] W. AbuSneineh and M. Zairi, "An evaluation framework for E-learning effectiveness in the Arab World," Int. Encycl. Educ., pp. 521-535, 2010.

[45] J. W. Fresen, "Factors influencing lecturer uptake of e-learning," Teach. English with Technol., vol. 11, no. 1, pp. 81-97, 2011.

[46] M. Anthony and H. Sue, "Critical success in e-learning: the human factor," 360o Ashridge, p. 32, 2006.

[47] R. Arora and I. Chhabra, "Extracting components and factors for quality evaluation of e-learning applications," in Engineering and Computational Sciences (RAECS), 2014 Recent Advances in, 2014, pp. $1-5$.
[48] N. Parsazadeh, N. M. M. Zainuddin, R. Ali, and A. Hematian, "A REVIEW ON THE SUCCESS FACTORS OF E-LEARNING," in The Second International Conference on e-Technologies and Networks for Development, 2013, pp. 42-49.

[49] A. Lee-Post, "e-Learning Success Model: An Information Systems Perspective.," Electron. J. e-learning, vol. 7, no. 1, pp. 61-70, 2009.

[50] M. Raspopovic, A. Jankulovic, J. Runic, and V. Lucic, "Success factors for e-learning in a developing country: A case study of Serbia," Int. Rev. Res. Open Distrib. Learn., vol. 15, no. 3, 2014.

[51] K. Sigama, B. M. Kalema, and R. M. Kekwaletswe, "Utilizing Web 2.0 and Free Open Source Software to advance e-learning in developing countries," in Sustainable e-Government and e-Business Innovations (ELEADERSHIP), 2012 e-Leadership Conference on, 2012, pp. 1-7.

[52] J. Webster and P. Hackley, "Teaching effectiveness in technologymediated distance learning," Acad. Manag. J., vol. 40, no. 6, pp. $1282-$ 1309, 1997.

[53] B. Cheawjindakarn, P. Suwannatthachote, A. Theeraroungchaisri, and others, "Critical success factors for online distance learning in higher education: A review of the literature," Creat. Educ., vol. 3, no. 8, p. 61, 2013.

[54] A. Keramati, M. Afshari-Mofrad, and A. Kamrani, "The role of readiness factors in E-learning outcomes: An empirical study," Comput. Educ., vol. 57, no. 3, pp. 1919-1929, 2011.

[55] O. F. Yew and M. Jambulingam, "Critical Success Factors of E-learning Implementation at Educational Institutions," J. Interdiscip. Res. Educ. Vol., vol. 5, no. 1, 2015.

[56] E. Ansong, S. L. Boateng, R. Boateng, and J. Effah, "Determinants of ELearning Adoption in Universities: Evidence from a Developing Country," in 2016 49th Hawaii International Conference on System Sciences (HICSS), 2016, pp. 21-30. 